\section{Kidney \\ Blood Pressure Research}

Kidney Blood Press Res 2017;42:89-98

DOI: 10.1159/000471899

Published onlıne: March 31, 2017

Accepted: December 21, 2016

This article is licensed under the Creative Commons Attribution-NonCommercial-NoDerivatives 4.0 InternaThis article is licensed under the Creative Commons Attribution-NonCommercial-NoDerivatives 4.0 Interna-
tional License (CC BY-NC-ND) (http:/www.karger.com/Services/OpenAccessLicense). Usage and distribution for commercial purposes as well as any distribution of modified material requires written permission.

\title{
Association of Interleukin-10 Polymorphisms (rs1800872, rs1800871, and rs1800896) with Predisposition to IgA Nephropathy in a Chinese Han Population: A Case-Control Study
}

\author{
Jie Gao Linting Wei ${ }^{a}$ Rongguo Fu ${ }^{a}$ Jiali Wei ${ }^{b}$ Dan Niuc Li Wang ${ }^{a} \quad H^{c}$ Geng Ge \\ Qiaoling $\mathrm{Yu}^{\mathrm{d}}$ Meng Wange Xinghan Liue Wanggang Zhang ${ }^{\mathrm{f}}$ \\ a'Department of Nephrology, Second Affiliated Hospital of Xi'an Jiaotong University, Xi'anM; \\ bDepartment of Nephrology, Hainan general hospital, Haikou; 'Department of Nephrology, First \\ Affiliated Hospital of Xi'an Jiaotong University; ${ }^{d}$ Department of Pathology; ${ }^{e}$ Department of Oncology; \\ 'Department of Hematology, Second Affiliated Hospital of Xi'an Jiaotong University, Xi'an, China
}

\section{Key Words}

IgA nephropathy $\bullet / L-10 \cdot$ Susceptibility $\cdot$ Case-control study

\begin{abstract}
Background/Aims: IgA nephropathy (IgAN) is a common form of primary glomerulonephritis worldwide. Previous studies indicated that IL-10 single nucleotide polymorphisms (SNP) play an important role in IgAN pathogenesis, but the results were controversy. This study aimed to investigate the association between IL-10 SNPs (rs1800872, rs1800871, and rs1800896) with IgAN in a Chinese Han population. Methods: We conducted a case-control study that included 351 patients with IgAN and 310 age-, gender- and ethnicity-matched healthy controls. Three promoter SNPs (rs1800872, rs1800871, and rs1800896) of IL-10 were genotyped by Sequenom MassARRAY. Odds ratios (ORs) with 95\% confidence intervals (CI) were used to assess the relationship with IgAN. Results: We found that the rs1800896 did not correlate with IgAN risk, whereas rs 1800872 and rs 1800871 were significantly associated with increased IgAN risk in all genetic models. The haplotype analysis indicated that the CCA haplotype was associated with increased IgAN risk $(\mathrm{OR}=1.36 ; 95 \% \mathrm{CI}=1.05-1.75)$. Moreover, there were no associations between these SNPs and blood pressure or gender, whereas the rs1800896 variant was correlated with higher 24-hour urine protein in patients with IgAN. Conclusion: Taken together, these results suggest that $I L-10$ is a susceptibility gene in patients with IgAN.
\end{abstract}

J. Gao and L. Wei contributed equally to this study and therefore share first authorship.

Jie Gao, MD and

Wanggang Zhang, MD, PHD
Department of Nephrology, and Department of Hematology, Second Affiliated Hospital of Xi'an Jiaotong University, Xi'an, Shaanxi Province 710004 (China)

E-Mail gxej_cn@sina.com and zhangwanggang2003@yahoo.com 


\section{Kidney Blood Pressure Research}

\section{Introduction}

IgA nephropathy (IgAN) is a common form of primary glomerulonephritis characterized by highly diverse clinical and pathological features [1]. IgAN diagnosis depends entirely on renal biopsies. This disease is characterized by the deposits of IgA in the glomerular mesangium along with the complement $\mathrm{C} 3$, IgG and /or IgM though maybe the intensity is low $[1,2]$. Most patients present with persistent hematuria or proteinuria, and only few undergo sustained clinical remission. The prognosis is also highly variable and the outcome is difficult to predict in affected individuals [3]. Another study by Tan et al. reveals that proteinuria is an independent risk factor in IgAN patients with severe renal pathological injuries but benign clinical features [4]. Although IgAN is benign during early stages of primary glomerular disease, about $50 \%$ of patients will progress to end-stage renal disease (ESRD) [5, 6]. A retrospective study in Czech IgAN patients show that GFR, hypertension and proteinuria are vital factors associated with the prognosis of IgAN [7]. A review by Tomino also states complement activation, podocyte injury and mast cell infiltration may affect diseases activity, development and progression in patients with IgAN [8]. Additionally, Wang et al. indicates that thapsigargin may be candidate drugs in treatment of IgAN [9]. Now, increasing evidences have found that genetic factors were associated with the development and / or progression of IgAN [10-16]. And indicates that IgAN is a polygenic disease, but the precise pathogenesis still remains unclear.

Interleukin-10 (IL-10) is a multifunctional cytokine, primarily produced by lymphocytes and monocytes. $I L-10$ often has bi-directional immuneregulating and anti-inflammatory functions [17]. It can inhibit the production of Th1 cytokines cloned IL-2 and the synthesis of interferon gamma and tumor necrosis factor cytokines [18]. Some promoter polymorphic sites of $I L-10$ gene have been described, and three SNPs at positions $-1082,-819$ and -592 from the transcription initiation site have been identified [19]. -1082 SNP (rs1800896) is a $\mathrm{G}$ to $A$ substitution and lies in a negative putative transcription factor binding site [20]. The $\mathrm{G}$ allele of rs1800896 is known to be correlated with high levels of in vitro $I L-10$ productions $[19,21]$. The - 819 SNP (rs1800871) is a C to T substitution with a dimorphic polymorphism, and is also reported correlated with $I L-10$ production [21, 22]. The -592 SNP (rs1800872) is a $\mathrm{C}$ to $\mathrm{A}$ substitution and locates in a region with a negative regulatory function $[20,21]$.

It is widely acknowledged that interleukins (ILs) involved in the proliferation of glomerular mesangial cells and lead to the release of some inflammatory factors [23-25]. The most important is the serum levels of $I L-10$ are elevated in patients with IgAN [26]. Together, all these data suggest that genetic variations, such as $I L-10$ SNPs, may be involved in the development and progression of IgAN [27]. Recent meta-analysis results revealed that variants of the $I L-1$ and $I L-1 R N$ genes were correlated with an increased risk of IgAN. However, similar results were not observed for the genes of $I L-6, I L-10$, or $I L-22 R$ [28]. Considering these conflicting results, the role of $I L-10$ in the pathogenesis of IgAN is worth further investigation. This study was designed to investigate the association between $I L$ 10 promoter SNPs (rs1800872, rs1800871, and rs1800896) and IgAN in a Chinese Han population.

\section{Materials and Methods}

\section{Ethics statement}

The study protocol was reviewed and approved by the Xi'an Jiaotong University Ethical Committee. Written informed consent was obtained from each participant after a full explanation of the study. The experimental protocol was carried out in accordance with the approved guidelines.

Subjects

Here, we report a hospital-based case-control study that was carried out by recruiting 351 patients 


\section{Kidney Blood Pressure Research}

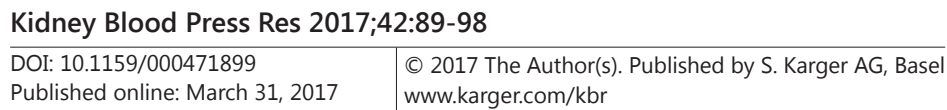

Published online: March 31, 2017 www.karger.com/kbr

Gao et al.: IL-10 Polymorphisms with Predisposition to IgA Nephropathy

Table 1. Primers used for this study

\begin{tabular}{lccc}
\hline SNP_ID & 1st-PCRP & 2nd-PCRP & UEP_SEQ \\
\hline rs1800872 & ACGTTGGATGAAAGGAGCCTGGAACACATC & ACGTTGGATGTCCTCAAAGTTCCCAAGCAG & GGACTGGCTTCCTACAG \\
rs1800871 & ACGTTGGATGATGCTAGTCAGGTAGTGCTC & ACGTTGGATGGGTGTACCCTTGTACAGGTG & GGGAACCTTGTACAGGTGATGTAA \\
rs1800896 & ACGTTGGATGATTCCATGGAGGCTGGATAG & ACGTTGGATGGACAACACTACTAAGGCTTC & CTAAGGCTTCTTTGGGA \\
\hline
\end{tabular}

with IgAN (229 males and 122 females, mean age of $32 \pm 11.9$ years) from Northwestern China at the First and Second Affiliated Hospital of Xi'an Jiaotong University from March 2009 to April 2014. IgAN diagnosis was confirmed by histopathological examination of renal biopsy in all cases. The controls consisted of 310 healthy subjects ( 186 males and 124 females, mean age of $35 \pm 12.6$ years) from routine healthy examinations in the same hospitals. All subjects were from the Chinese Han population living in Northwestern China. Patients with comorbidities such as lupus nephritis, purpura nephritis, chronic liver cirrhosis, diabetes mellitus, hypertension, and other secondary IgAN were excluded. Demographic and clinical information were collected, including age, gender, serum creatinine leve (SCr), blood urea nitrogen (BUN), serum albumin level (ALB), serum uric acid (UA), serum IgA level, serum cholesterol level (Cho), 24-hour urine protein, blood pressure, and histopathological grade (Oxford classification [29]).

\section{Genotyping methods}

Blood samples were collected into tubes containing ethylenediaminetetraacetic acid (EDTA). After centrifugation, the specimens were stored at $-80^{\circ} \mathrm{C}$ until further analysis. A standard phenol-chloroform extraction method was used to extract genomic DNA from whole blood (GoldMag Co. Ltd, Xi'an City, China). DNA concentration was measured by using an ultraviolet spectrophotometer (Nanodrop, Thermo Scientific, Waltham, MA). Three promoter SNPs (rs1800872, rs1800871, and rs1800896), which captured the majority of the known common variants of $I L-10$ according to Chinese population data from HapMap (http://www.hapmap.org), were selected for analysis in our study. Sequenom MassARRAY Assay Design 3.0 Software (Sequenom, San Diego, CA, USA) was used to design a multiplex SNP MassEXTEND assay as previously described [30,31]. SNP genotyping was performed by Sequenom MassARRAY RS1000 according to the standard protocol recommended by the manufacturer [30]. The corresponding primers used for each SNP in our study are listed in Table 1. Sequenom Typer 3.0 software was used for data analysis [30-32].

\section{Statistical analysis}

Statistical analysis was performed with SPSS 18.0 for Windows (PASW Statistics, SPSS Inc., Chicago, IL, USA). SNP frequencies in control subjects were tested for departure from Hardy-Weinberg Equilibrium (HWE). A Student's $t$ test was used to determine if the differences in age between the case and control groups were statistically significant. Chi-square (Pearson's $\chi^{2}$ ) tests were used where necessary to calculate the odds ratios (ORs) with 95\% confidence intervals (CIs) and corresponding $P$ values to determine the relationships between the genotypes, IgAN risk, and clinical variables. Unconditional multivariate logistic regression adjusted for age and sex was performed for further association analysis. Five models (codominant, dominant, recessive, overdominant, and log-additive) were used to evaluate associations of the SNPs with IgAN risk in this study. $P<0.05$ was considered statistically significant and all statistical tests were two-sided.

\section{Results}

\section{Demographic and Characteristics of the Patients and Controls}

In total, 661 subjects participated in this study for genetic association analysis, including 351 patients with IgAN (229 males, 122 females; age at diagnosis: $32 \pm 11.9$ years) and 310 matched controls (186 males, 124 females; age at diagnosis: $35 \pm 12.6$ years). The genotype distributions of the selected SNPs (rs1800872, rs1800871, and rs1800896) in the case and control groups were in Hardy-Weinberg equilibrium $(P=0.12,0.14$, and 0.59 , respectively). Basic characteristics of the cases and controls such as age and gender are listed in Table 2. Hypertension was defined as blood pressure $\geq 140 / 90 \mathrm{mmHg}$ and / 


\section{Kidney Blood Pressure Research}

Kidney Blood Press Res 2017;42:89-98

\begin{tabular}{|l|l|}
\hline DOI: 10.1159/000471899 & (C) 2017 The Author(s). Published by S. Karger AG, Base
\end{tabular}

Published online: March 31, 2017

www.karger.com/kbr or diastolic pressure $\geq 90 \mathrm{mmHg}$ on three occasions at diagnosis, or the use of antihypertensive medication to achieve normal blood pressure. 24hour urine protein was divided into 2 groups, $<3.5 \mathrm{~g}$ and $\geq 3.5 \mathrm{~g}$. Among the 351 patients, 221 were classified to M1, 196 had endocapillary hypercellularity, 103 had segmental sclerosis, and there were about 230 , 73 and 48 patients classified to $\mathrm{T} 0, \mathrm{~T} 1$ and $\mathrm{T} 2$, respectively.

Distributions of allele and genotype frequencies between patients with IgAN and healthy controls

The distributions of allele and genotype frequencies of the three $I L$-10 SNPs in patients with IgAN and healthy controls are listed in Table 3. Assuming that the minor allele of each SNP was a risk allele compared with the wild type allele. Chi-square tests revealed that there were significant differences in the $\mathrm{C}$ allele frequencies of rs1800872 and
Table 2. Characteristics of IgAN patients and healthy controls

\begin{tabular}{|c|c|c|c|}
\hline $\begin{array}{l}\text { Total subjects } \\
(\mathrm{n}=661)\end{array}$ & IgAN & Control & $P$ \\
\hline Number (n) & 351 & 310 & \\
\hline Male/Female & $229 / 122$ & $186 / 124$ & $0.16^{\mathrm{a}}$ \\
\hline Age (mean $\pm S D)$ & $32 \pm 11.9$ & $35 \pm 12.6$ & $0.45^{b}$ \\
\hline \multicolumn{4}{|c|}{ Urine Protein $(\mathrm{g} / 24 \mathrm{~h})$} \\
\hline$<3.5$ & $272(77.5 \%)$ & & \\
\hline \multicolumn{4}{|c|}{$79(22.5 \%)$} \\
\hline \multicolumn{4}{|c|}{ blood pressure (mmHg) } \\
\hline$<140 / 90$ & $194(55.3 \%)$ & & \\
\hline \multicolumn{4}{|c|}{$157(44.7 \%)$} \\
\hline \multicolumn{4}{|c|}{ Oxford classification } \\
\hline M(M0/M1) & $\begin{array}{c}130 / 221 \\
(37.0 \% / 63 \%)\end{array}$ & & \\
\hline $\mathrm{E}(\mathrm{E} 0 / \mathrm{E} 1)$ & $\begin{array}{c}155 / 196 \\
(44.2 \% / 55.8 \%)\end{array}$ & & \\
\hline $\mathrm{S}(\mathrm{S} 0 / \mathrm{S} 1)$ & $\begin{array}{c}248 / 103 \\
(70.7 \% / 29.3 \%)\end{array}$ & & \\
\hline $\mathrm{T}(\mathrm{T} 0 / \mathrm{T} 1 / \mathrm{T} 2)$ & $\begin{array}{c}230 / 73 / 48 \\
(65.5 \% / 20.8 \% / 13.7 \%)\end{array}$ & & \\
\hline Serum $\operatorname{Cr}(\mu \mathrm{mol} / \mathrm{L})$ & $159.5 \pm 146.0$ & & \\
\hline BUN (mmol/L) & $8.2 \pm 5.9$ & & \\
\hline Serum ALB (g/L) & $34.0 \pm 7.9$ & & \\
\hline Serum IgA $(\mathrm{g} / \mathrm{L})$ & $2.8 \pm 1.7$ & & \\
\hline \multicolumn{4}{|c|}{$\begin{array}{l}\text { a values was calculated from two-sided chi-square test; } \mathrm{b} P \text { values } \\
\text { were calculated by Student's } t \text { tests. Abbreviations: IgAN = IgA } \\
\text { Nephropathy, } \mathrm{SCr}=\text { serum creatinine leve, BUN = blood urea } \\
\text { nitrogen, } \mathrm{ALB}=\text { serum albumin level }\end{array}$} \\
\hline
\end{tabular}

rs1800871 between the cases and controls ( $P=0.03$ for both), whereas the $\mathrm{A}$ and $\mathrm{G}$ alleles of rs1800896 did not correlated with IgAN risk $(P=0.99$, Table 3$)$.

As for genotype frequencies, significant differences were observed between the cases and controls in the CC genotypes of rs1800872 and rs1800871 in codominant model with increased risks of IgAN $(P=0.04,0.05$ for both, before and after adjustment for age and gender, Table 3). The CA and CC genotypes of rs1800872 and TC and CC genotypes of rs1800871 in $I L-10$ gene in dominant model also had increased risks of $\operatorname{IgAN}(P=0.01,0.02$ for both, before and after adjustment for age and gender, Table 3). Similar results in Logadditive model of rs1800872 and rs1800871 in $I L-10$ gene $(P=0.03,0.02$ for both, before and after adjustment for age and gender, Table 3). While, the CA genotype of rs1800872 and TC genotypes of rs1800871 in $I L-10$ gene in over-dominant model only showed increased risks of IgAN before the adjustment $(P=0.04$ for both, Table 3). For rs1800896, the genotype distributions were not significantly associated with the risk of IgAN before or after adjustment (Table 3).

Haplotype distributions between patients with IgAN and healthy controls

We further performed haplotype association analysis for the three $I L-10$ SNPs and the risk of IgAN. The haplotypes with observed frequencies of more than 0.05 are listed in Table 4. The ATA haplotype was more frequent in patients with IgAN. Further association analysis for each of these haplotypes and the risk of IgAN indicated that the CCA haplotype may be a risk factor of IgAN $(\mathrm{OR}=1.36 ; 95 \% \mathrm{CI}=1.05-1.75 ; P=0.02)$. The other haplotypes did not correlate with $\operatorname{IgAN}(P=0.66)$.

Associations between genotype distributions and IgAN clinical variables

Since the frequencies of the minor homozygous variants of the three $I L-10$ SNPs were relatively low in patients with IgAN in this study, they were combined with their corresponding 


\section{Kidney \\ Blood Pressure Research}

Table 3. Frequency distributions of IL-10 allele and genotype and their associations with the risk of developing IgAN

\begin{tabular}{|c|c|c|c|c|c|c|c|c|}
\hline SNP & Model & $\begin{array}{c}\text { Geno- } \\
\text { type }\end{array}$ & Control & Case & OR $(95 \% \mathrm{CI})$ & $P^{*}$ & $\mathrm{OR}(95 \% \mathrm{CI})^{\dagger}$ & $P^{\#}$ \\
\hline \multirow[t]{12}{*}{ rs1800872 } & Codominant & $\mathrm{A} / \mathrm{A}$ & $152(49.2 \%)$ & $138(39.4 \%)$ & 1.00 & \multirow{3}{*}{0.04} & 1.00 & \multirow{3}{*}{0.05} \\
\hline & & $\mathrm{C} / \mathrm{A}$ & $121(39.2 \%)$ & $165(47.1 \%)$ & $1.50(1.08-2.09)$ & & $1.57(1.02-2.42)$ & \\
\hline & & $\mathrm{C} / \mathrm{C}$ & $36(11.7 \%)$ & $47(13.4 \%)$ & $1.44(0.88-2.35)$ & & $1.94(0.99-3.81)$ & \\
\hline & \multirow[t]{2}{*}{ Dominant } & $\mathrm{A} / \mathrm{A}$ & $152(49.2 \%)$ & $138(39.4 \%)$ & 1.00 & \multirow{3}{*}{0.01} & 1.00 & \multirow[b]{2}{*}{0.02} \\
\hline & & $\mathrm{C} / \mathrm{A}-\mathrm{C} / \mathrm{C}$ & $157(50.8 \%)$ & $212(60.6 \%)$ & $1.49(1.09-2.03)$ & & $1.64(1.09-2.47)$ & \\
\hline & \multirow[t]{2}{*}{ Recessive } & $\mathrm{A} / \mathrm{A}-\mathrm{C} / \mathrm{A}$ & $273(88.3 \%)$ & $303(86.6 \%)$ & 1.00 & & 1.00 & \multirow[b]{2}{*}{0.17} \\
\hline & & $\mathrm{C} / \mathrm{C}$ & $36(11.7 \%)$ & 47 (13.4\%) & $1.18(0.74-1.87)$ & 0.49 & $1.56(0.82-2.96)$ & \\
\hline & \multicolumn{3}{|c|}{ Overdominant A/A-C/C 188 (60.8\%) } & $185(52.9 \%)$ & 1.00 & \multirow[t]{2}{*}{0.04} & 1.00 & \multirow{3}{*}{$\frac{0.13}{0.02}$} \\
\hline & & $\mathrm{C} / \mathrm{A}$ & $121(39.2 \%)$ & $165(47.1 \%)$ & $1.39(1.02-1.89)$ & & $1.38(0.91-2.08)$ & \\
\hline & Log-additive & --- & --- & --- & $1.28(1.02-1.61)$ & 0.03 & $1.45(1.07-1.96)$ & \\
\hline & \multirow{2}{*}{ Allele } & A & 425 & 441 & 1.00 & \multirow[b]{2}{*}{0.03} & --- & --- \\
\hline & & $\mathrm{C}$ & 193 & 259 & $1.29(1.03-1.63)$ & & --- & --- \\
\hline \multirow{12}{*}{ rs1800871 } & Codominant & $\mathrm{T} / \mathrm{T}$ & $152(49 \%)$ & $138(39.3 \%)$ & 1.00 & \multirow{3}{*}{0.04} & 1.00 & \multirow{3}{*}{0.05} \\
\hline & & $\mathrm{T} / \mathrm{C}$ & 122 (39.4\%) & $166(47.3 \%)$ & $1.50(1.08-2.08)$ & & $1.57(1.02-2.42)$ & \\
\hline & & $\mathrm{C} / \mathrm{C}$ & $36(11.6 \%)$ & 47 (13.4\%) & $1.44(0.88-2.35)$ & & $1.94(0.99-3.81)$ & \\
\hline & \multirow[t]{2}{*}{ Dominant } & $\mathrm{T} / \mathrm{T}$ & 152 (49\%) & $138(39.3 \%)$ & 1.00 & \multirow[t]{2}{*}{0.01} & 1.00 & \multirow[b]{2}{*}{0.02} \\
\hline & & $\mathrm{T} / \mathrm{C}-\mathrm{C} / \mathrm{C}$ & $158(51 \%)$ & $213(60.7 \%)$ & $1.48(1.09-2.02)$ & & $1.64(1.09-2.47)$ & \\
\hline & \multirow[t]{2}{*}{ Recessive } & T/T-T/C & 274 (88.4\%) & $304(86.6 \%)$ & 1.00 & \multirow[t]{2}{*}{0.49} & 1.00 & \multirow[b]{2}{*}{0.17} \\
\hline & & $\mathrm{C} / \mathrm{C}$ & $36(11.6 \%)$ & 47 (13.4\%) & $1.18(0.74-1.87)$ & & $1.57(0.83-2.97)$ & \\
\hline & \multicolumn{3}{|c|}{ Overdominant T/T-C/C 188 (60.6\%) } & $185(52.7 \%)$ & 1.00 & \multirow[t]{2}{*}{0.04} & 1.00 & \multirow{3}{*}{$\frac{0.13}{0.02}$} \\
\hline & & $\mathrm{T} / \mathrm{C}$ & $122(39.4 \%)$ & $166(47.3 \%)$ & $1.38(1.01-1.88)$ & & $1.37(0.91-2.07)$ & \\
\hline & Log-additive & --- & --- & --- & $1.28(1.02-1.61)$ & 0.03 & $1.45(1.07-1.96)$ & \\
\hline & Allele & $\mathrm{T}$ & 426 & 442 & 1.00 & & --- & \\
\hline & & $\mathrm{C}$ & 194 & 260 & $1.29(1.03-1.62)$ & 0.03 & --- & --- \\
\hline rs1800896 & Codominant & $\mathrm{A} / \mathrm{A}$ & $260(83.9 \%)$ & $293(83.5 \%)$ & 1.00 & 0.81 & 1.00 & \\
\hline & & $\mathrm{G} / \mathrm{A}$ & 47 (15.2\%) & 56 (15.9\%) & $1.06(0.69-1.61)$ & & $1.73(0.97-3.10)$ & 0.18 \\
\hline & & $\mathrm{G} / \mathrm{G}$ & $3(1 \%)$ & $2(0.6 \%)$ & $0.59(0.10-3.57)$ & & $0.93(0.09-9.24)$ & \\
\hline & Dominant & $\mathrm{A} / \mathrm{A}$ & $260(83.9 \%)$ & $293(83.5 \%)$ & 1.00 & 0.89 & 1.00 & \\
\hline & & $\mathrm{G} / \mathrm{A}-\mathrm{G} / \mathrm{G}$ & $50(16.1 \%)$ & $58(16.5 \%)$ & $1.03(0.68-1.56)$ & & $1.67(0.95-2.96)$ & 0.08 \\
\hline & Recessive & $\mathrm{A} / \mathrm{A}-\mathrm{G} / \mathrm{A}$ & 307 (99\%) & 349 (99.4\%) & 1.00 & & 1.00 & \\
\hline & & $\mathrm{G} / \mathrm{G}$ & $3(1 \%)$ & $2(0.6 \%)$ & $0.59(0.10-3.53)$ & 0.56 & $0.86(0.09-8.42)$ & 0.90 \\
\hline & Overdominant & $A / A-G / G$ & $263(84.8 \%)$ & 295 (84\%) & 1.00 & & 1.00 & \\
\hline & & $\mathrm{G} / \mathrm{A}$ & $47(15.2 \%)$ & $56(15.9 \%)$ & $1.06(0.70-1.62)$ & 0.78 & $1.73(0.97-3.10)$ & 0.06 \\
\hline & Log-additive & --- & --- & --- & $1.00(0.68-1.47)$ & 1.00 & $1.53(0.91-2.59)$ & 0.11 \\
\hline & Allele & A & 567 & 642 & 1.00 & & --- & --- \\
\hline & & G & 53 & 60 & $1.00(0.68-1.47)$ & 1.00 & --- & --- \\
\hline
\end{tabular}

${ }^{*}$ Two-sided chi-square test for the distributions of genotype and allele frequencies before adjustment. \# Two-sided chisquare test for the distributions of genotype and allele frequencies after adjustment. ${ }^{\dagger}$ Adjusted for age and gender. OR = odd ratio; $\mathrm{CI}=$ confidence interval; $P<0.05$ was considered statistically significant.

Table 4. Frequencies of three IL-10 variants (rs1800872, rs1800871, rs1800896) and the associations with the risk of IgAN

\begin{tabular}{lcccccccc}
\hline \multirow{2}{*}{ Haplotype } & Fre- & \multicolumn{2}{c}{ Ratio Counts } & \multicolumn{2}{c}{ Frequencies } & Chi- & \multirow{2}{*}{ OR(95\%CI) } & \multirow{2}{*}{$P$} \\
\cline { 3 - 6 } & quency & case & Control & case & Control & Square & & \\
\hline ATA & 0.656 & $442.0: 260.0$ & $424.0: 194.0$ & 0.630 & 0.686 & 4.642 & 1.00 & --- \\
CCA & 0.259 & $200.0: 502.0$ & $142.0: 476.0$ & 0.285 & 0.230 & 5.203 & $1.36(1.05-1.75)$ & 0.019 \\
CCG & 0.085 & $60.0: 642.0$ & $52.0: 566.0$ & 0.085 & 0.084 & 0.007 & $1.09(0.74-1.62)$ & 0.66 \\
\hline
\end{tabular}

OR = odds ratio, $95 \% \mathrm{CI}=95 \%$ confidence interval.

heterozygous variants in the clinical variable analysis. We found that there was no statistical association between genotype distribution and gender, blood pressure status or Oxford classification (data not shown). Besides, no statistical correlation differences were observed for rs1800872 and rs1800871 between cases and controls. However, the GG genotype in the codominant model, GA/GG genotypes in the dominant model, and GA genotype in the overdominant model of the rs1800896 in $I L-10$ gene correlated with higher 24-hour urine protein in patients with IgAN $(P=0.04,0.03$, and 0.02 , respectively, Table 5). 


\section{Kidney Blood Pressure Research}

Table 5. Association between genotype distribution and urine protein (up) in patients with IgAN

\begin{tabular}{|c|c|c|c|c|c|c|c|c|}
\hline \multirow[t]{2}{*}{ SNP ID } & \multirow[t]{2}{*}{ Model } & \multirow{2}{*}{ Genotype } & \multicolumn{2}{|c|}{ Urine Protein (UP) } & \multirow{2}{*}{$\begin{array}{c}\text { OR } \\
(95 \% \mathrm{CI})\end{array}$} & \multirow[t]{2}{*}{$P$} & \multirow{2}{*}{ AIC } & \multirow{2}{*}{ BIC } \\
\hline & & & $\mathrm{UP}<3.5 \mathrm{~g} \mathrm{n}(\%)$ & $\mathrm{UP} \geq 3.5 \mathrm{~g} \mathrm{n}(\%)$ & & & & \\
\hline \multirow{9}{*}{ rs1800872 } & \multirow[t]{3}{*}{ Codominant } & $\mathrm{A} / \mathrm{A}$ & 110 (41.2\%) & 23 (30.7\%) & 1.00 & \multirow{3}{*}{0.24} & \multirow{3}{*}{363} & \multirow{3}{*}{374.5} \\
\hline & & $\mathrm{C} / \mathrm{A}$ & $122(45.7 \%)$ & $41(54.7 \%)$ & $1.61(0.91-2.85)$ & & & \\
\hline & & $\mathrm{C} / \mathrm{C}$ & $35(13.1 \%)$ & $11(14.7 \%)$ & $1.50(0.67-3.39)$ & & & \\
\hline & Dominant & A/A & $110(41.2 \%)$ & $23(30.7 \%)$ & $\begin{array}{c}1.00 \\
1.0274\end{array}$ & \multirow[t]{2}{*}{0.094} & \multirow[t]{2}{*}{361} & \multirow[t]{2}{*}{368.7} \\
\hline & \multirow{2}{*}{ Recessive } & $\frac{\mathrm{C} / \mathrm{A}-\mathrm{C} / \mathrm{C}}{\mathrm{A} / \mathrm{A}-\mathrm{C} / \mathrm{A}}$ & $\frac{157(58.8 \%)}{232(86.9 \%)}$ & $\frac{52(69.3 \%)}{64(85.3 \%)}$ & $\frac{1.58(0.92-2.74)}{1.00}$ & & & \\
\hline & & $\mathrm{C} / \mathrm{C}$ & $35(13.1 \%)$ & $11(14.7 \%)$ & $1.14(0.55-2.37)$ & 0.73 & 363.7 & 371.3 \\
\hline & \multirow[t]{2}{*}{ Overdominant } & $\mathrm{A} / \mathrm{A}-\mathrm{C} / \mathrm{C}$ & $145(54.3 \%)$ & $34(45.3 \%)$ & 1.00 & \multirow{2}{*}{0.17} & \multirow{2}{*}{361.9} & \multirow{2}{*}{369.6} \\
\hline & & $\mathrm{C} / \mathrm{A}$ & $122(45.7 \%)$ & $41(54.7 \%)$ & $1.43(0.86-2.40)$ & & & \\
\hline & Log-additive & $-{ }_{--}$ & --- & --- & $1.30(0.89-1.89)$ & 0.17 & 361.9 & 369.6 \\
\hline \multirow{10}{*}{ rs1800871 } & Codominant & $\mathrm{T} / \mathrm{T}$ & $110(41 \%)$ & $23(30.7 \%)$ & 1.00 & \multirow{3}{*}{0.25} & \multirow{3}{*}{363.5} & \multirow{3}{*}{375.1} \\
\hline & & $\mathrm{T} / \mathrm{C}$ & $123(45.9 \%)$ & $41(54.7 \%)$ & $1.59(0.90-2.82)$ & & & \\
\hline & & $\mathrm{C} / \mathrm{C}$ & $35(13.1 \%)$ & $11(14.7 \%)$ & $1.50(0.67-3.39)$ & & & \\
\hline & Dominant & $\mathrm{T} / \mathrm{T}$ & $110(41 \%)$ & $23(30.7 \%)$ & 1.00 & 0.099 & 3616 & 3692 \\
\hline & & $\mathrm{T} / \mathrm{C}-\mathrm{C} / \mathrm{C}$ & $158(59 \%)$ & $52(69.3 \%)$ & $1.57(0.91-2.72)$ & 0.099 & 361.6 & 369.2 \\
\hline & Recessive & $\mathrm{T} / \mathrm{T}-\mathrm{T} / \mathrm{C}$ & $233(86.9 \%)$ & $64(85.3 \%)$ & 1.00 & & & \\
\hline & & $\mathrm{C} / \mathrm{C}$ & $35(13.1 \%)$ & $11(14.7 \%)$ & $1.14(0.55-2.38)$ & 0.72 & 364.2 & $3 / 1.8$ \\
\hline & Overdominant & $\mathrm{T} / \mathrm{T}-\mathrm{C} / \mathrm{C}$ & $145(54.1 \%)$ & $34(45.3 \%)$ & 1.00 & 018 & 3625 & 370 \\
\hline & & $\mathrm{T} / \mathrm{C}$ & $123(45.9 \%)$ & $41(54.7 \%)$ & $1.42(0.85-2.38)$ & 0.18 & 362.5 & $3 / 0.2$ \\
\hline & Log-additive & --- & --- & --- & $1.30(0.89-1.88)$ & 0.18 & 362.5 & 370.1 \\
\hline & Codominant & $\mathrm{A} / \mathrm{A}$ & $230(85.8 \%)$ & $56(74.7 \%)$ & 1.00 & & & \\
\hline & & G/A & $36(13.4 \%)$ & $19(25.3 \%)$ & $2.17(1.16-4.06)$ & 0.038 & 359.8 & 371.3 \\
\hline & & $\mathrm{G} / \mathrm{G}$ & $2(0.8 \%)$ & $0(0 \%)$ & $0.00(0.00-\mathrm{NA})$ & & & \\
\hline & Dominant & $\mathrm{A} / \mathrm{A}$ & $230(85.8 \%)$ & $56(74.7 \%)$ & 1.00 & 0028 & 3594 & 3671 \\
\hline rc1800896 & & $\mathrm{G} / \mathrm{A}-\mathrm{G} / \mathrm{G}$ & $38(14.2 \%)$ & $19(25.3 \%)$ & $2.05(1.10-3.83)$ & $0.0 \angle 8$ & 359.4 & \\
\hline TS1000090 & Recessive & A/A-G/A & $266(99.2 \%)$ & $75(100 \%)$ & 1.00 & 0.32 & 363.3 & 371 \\
\hline & & $\mathrm{G} / \mathrm{G}$ & $2(0.8 \%)$ & $0(0 \%)$ & $0.00(0.00-\mathrm{NA})$ & 0.32 & 363.3 & $3 / 1$ \\
\hline & Overdominant & A/A-G/G & $232(86.6 \%)$ & $56(74.7 \%)$ & 1.00 & 0.018 & 358.6 & 366.3 \\
\hline & & $\mathrm{G} / \mathrm{A}$ & $36(13.4 \%)$ & $19(25.3 \%)$ & $2.19(1.17-4.10)$ & & 358.6 & 306.3 \\
\hline & Log-additive & --- & --- & --- & $1.83(1.01-3.31)$ & 0.051 & 360.5 & 368.2 \\
\hline
\end{tabular}

\section{Discussion}

In this study, three promoter SNPs (rs1800872, rs1800871, and rs1800896) in the $I L$ 10 gene were examined to establish the role of $I L-10$ in susceptibility to IgAN in a Chinese Han population. In humans, $I L-10$ is located on chromosome 1 and encodes for 5 exons and 4 introns [33]. To date, most studies focused on the variants at rs1800872, rs1800871 and rs1800896, which are located at the transcription start site and shown to associate with IL-10 production [21]. Haplotypes comprising these SNPs (rs1800872, rs1800871, and rs1800896) also correlate with $I L-10$ serum levels [21]. Previous studies also demonstrated that $I L-10$ played a vital role in the development of the primary glomerulonephritis in many aspects, including IgAN [34-37]. Since it was determined that rs1800896 GG, rs1800871 CC and rs1800872 CC genotypes were associated with high IL-10 production, whereas rs1800896 AA, rs1800871 TT and rs1800872 AA genotypes with low IL-10 production. But with regard to the alleles, correlation with IL-10 levels is still ambiguous [19, 38-39]. Although some reports showed that genetic variants of $I L-10$ contribute to the pathogenesis of certain diseases, and also the serum levels of $I L-10$ increased in patients with IgAN [26], the study between clinical relevance of $I L-10$ promoter polymorphisms and IgAN remains unclear.

Here, we performed a case-control study to investigate the relationships between three $I L-10$ SNPs and IgAN in Chinese Han patients. Our results indicate that the alleles and genotypes of rs 1800872 and rs 1800871 were associated with increased risk of IgAN in some 


\section{Kidney Blood Pressure Research}

Kidney Blood Press Res 2017;42:89-98

\begin{tabular}{|l|l|}
\hline DOI: 10.1159/000471899 & (C) 2017 The Author(s). Published by S. Karger AG, Base
\end{tabular}

Published online: March 31, 2017

www.karger.com/kb

genetic models. In contrast, in a Korean population, Chin et al. demonstrated that rs1800872 and rs1800871 were not associated with IgAN susceptibility [34]. Wang et al. showed similar results in a Chinese population, where rs 1800872 was not associated with IgAN risk [36]. Interestingly, our results were inconsistent with these aforementioned studies. However, sample size, differences in environmental backgrounds, population admixture, genotyping method, different treatment protocols, and different selection criteria for responder and non-responder groups may explain these discrepancies.

Unlike rs1800872 and rs1800871, no statistically significant association between rs1800896 variant and the susceptibility to IgAN was observed. Consequently, the frequency of G alleles of rs 1800896 was not statistically different between patients with IgAN and healthy controls. Interestingly, when considering clinical variables, the GG, GA/GG and GA genotypes of rs1800896 correlated with higher proteinuria in patients with IgAN. Nevertheless, Bantis et al. revealed that rs1800896 is an important variant in the progression of IgAN in a Caucasian population [35]. In light of this difference, we should point out the limitations of our study, including a short follow-up duration and highly variable patient characteristics. As for the $\mathrm{G}$ alleles of rs1800896, Chin et al. highlighted that their frequency was lower in patients with IgAN than in controls in a Korean population [34]. Conversely, Wang et al. concluded that the frequency of G allele of rs1800896 was higher in Chinese patients with IgAN [36]. Our results do not settle these controversies. The above-mentioned intrinsic limitations may contribute to these conflicting results and discrepancies. Notwithstanding these limitations, our data suggest that rs1800896 plays a role in the development of IgAN because of the association between rs1800896 and proteinuria content, as it is widely accepted that the amount of urine protein is crucial for every stage of IgAN.

Despite the aforementioned inconsistencies, there are some similarities between our results and those of others. In the present study, we found that the allele frequencies of the patients with IgAN and controls herein of Chinese descent were very similar to those of individuals of Korean descent [34], but were markedly different from those of a U.K. white population [40], indicating differences based on ethnic populations. However, other reports indicated that the frequency of the G allele of rs1800896, which was reported to be related to higher $I L-10$ production, was lower in patients with IgAN $[19,40]$. Although the frequency of the G allele of rs1800896 in patients with IgAN and controls was lower in this study when compared to that in a U.K. Caucasian population, it did not reach statistical significance $(P$ $>0.05$ ). With regard to genotypes, we found that few controls and patients presented the rs1800896 GG genotype, which is in line with the Korean study, in which none of the subjects presented the GG genotype [34].

The three $I L-10$ SNPs (rs1800872, rs1800871, and rs1800896) are widely reported as three haplotypes: CCA, ATA, and CCG. Moreover, some classify these $I L-10$ haplotype variations into three categories depending on $I L-10$ production (i.e., high, intermediate, and low) $[19,40]$. Specifically, CCG homozygous patients are regarded as high producers, CCG heterozygous patients as intermediate producers, and CCG negative patients are considered low producers. Regarding the ATA haplotype, the frequency of ATA was $63.0 \%$ and $68.6 \%$ in our case and control groups, respectively. Our results are similar to those of the Korean study where the frequency was $70.4 \%$ in patients with IgAN and $62.0 \%$ in healthy controls [34], which was markedly different from the results of the U.K. Caucasian study in healthy controls (16.4\% in Southeast England and 21.8\% in Manchester) [40]. Additionally, the frequency of CCA was $28.5 \%$ and $23.0 \%$ in our IgAN patients and control groups, respectively. These results are also similar to those of the Korean population, $26.9 \%$ and $28.5 \%$, respectively. The frequency of CCG in patients with IgAN and controls was $8.5 \%$ and $8.4 \%$, respectively, which is in agreement with the results of the study on a Korean population (2.8\% and 9.5\%) [34]. Although it was reported that lower levels of $I L-10$ production may predispose to inflammation and contribute to injuries to the kidney [34]. Unfortunately, we did not detect the serum levels of $I L-10$ in cases and controls. 


\section{Kidney Blood Pressure Research}

Although future investigations are warranted, our data shows that these $I L-10$ SNPs may be rare in the target population of individuals in Northwest China. In this regard, it may be worthwhile to expand the study to decrease intrinsic limitations. To reach a more definitive conclusion, further gene-gene, gene-race, and gene-environment interaction studies with larger sample sizes are still needed.

\section{Conclusion}

In summary, the present study demonstrated that the $I L-10$ promoter variants rs1800871, rs1800872, and CCA haplotype were significantly associated with an increased risk of IgAN. The rs1800896 variant was correlated with higher 24-hour urine protein in patients with IgAN. These results indicate that $I L-10$ promoter polymorphism plays a role in the development of IgAN in Northwest Chinese Han population.

\section{Disclosure Statement}

The authors declare that they do not have any conflict of interests.

\section{Acknowledgements}

This work was supported by National Natural Science Foundation of China (No. $81470968,81100530)$ and the Science and technology project of Shaanxi Province $(2014 \mathrm{~K}$ 11- 02-04-05).

\section{References}

-1 Wyatt RJ, Julian BA: Iga nephropathy. N Engl J Med 2013;368:2402-2414.

$\longrightarrow 2$ Jennette JC: The immunohistology of IgA nephropathy. Am J Kidney Dis 1988;12:348-352.

-3 D'Amico G: Natural history of idiopathic iga nephropathy: Role of clinical and histological prognostic factors. Am J Kidney Dis 2000;36:227-237.

4 Tan M, Li W, Zou G, Zhang C, Fang J: Clinicopathological features and outcomes of iga nephropathy with hematuria and/or minimal proteinuria. Kidney Blood Press Res 2015;40:200-206.

5 Maisonneuve P, Agodoa L, Gellert R, Stewart JH, Buccianti G, Lowenfels AB, Wolfe RA, Jones E, Disney APS, Briggs D, McCredie M, Boyle P: Distribution of primary renal diseases leading to end-stage renal failure in the united states, europe, and australia/new zealand: Results from an international comparative study. Am J Kidney Dis 2000;35:157-165.

6 Briganti EM, Dowling J, Finlay M, Hill PA, Jones CL, Kincaid-Smith PS, Sinclair R, McNeil JJ, Atkins RC: The incidence of biopsy-proven glomerulonephritis in australia. Nephrol Dial Transplant 2001;16:1364-1367.

7 Maixnerova D, Neprasova M, Skibova J, Mokrisova J, Rysava R, Reiterova J, Jancova E, Merta M, Zadrazil J, Honsova E, Tesar V: Iga nephropathy in czech patients--are we able reliably predict the outcome? Kidney Blood Press Res 2014;39:555-562.

8 Tomino Y: Pathogenesis and treatment of chronic kidney disease: A review of our recent basic and clinical data. Kidney Blood Press Res 2014;39:450-489.

-9 Wang J, Cao J: Gene expression analysis in tubule interstitial compartments reveals candidate agents for iga nephropathy. Kidney Blood Press Res 2014;39:361-368.

10 Delbarba E, Pedroni B, Dallera N, Izzi C, Scolari F: Genetics of mesangial IgA nephropathy. G Ital Nefrol 2015;32 Suppl 64. pii: gin/32.S64.12. 


\section{Kidney \\ Blood Pressure Research}

\begin{tabular}{l|l}
\hline Kidney Blood Press Res 2017;42:89-98 \\
\hline $\begin{array}{l}\text { DOI: 10.1159/000471899 } \\
\text { Published online: March 31, } 2017\end{array}$ & $\begin{array}{l}\text { (c) } 2017 \text { The Author(s). Published by S. Karger AG, Basel } \\
\text { www.karger.com/kbr }\end{array}$
\end{tabular}

Gao et al.: IL-10 Polymorphisms with Predisposition to IgA Nephropathy

11 Gharavi AG, Kiryluk K, Choi M, Li Y, Hou P, Xie J, Sanna-Cherchi S, Men CJ, Julian BA, Wyatt RJ, Novak J, He JC, Wang H, Lv J, Zhu L, Wang W, Wang Z, Yasuno K, Gunel M, Mane S, Umlauf S, Tikhonova I, Beerman I, Savoldi S, Magistroni R, Ghiggeri GM, Bodria M, Lugani F, Ravani P, Ponticelli C, Allegri L, Boscutti G, Frasca G, Amore A, Peruzzi L, Coppo R, Izzi C, Viola BF, Prati E, Salvadori M, Mignani R, Gesualdo L, Bertinetto F, Mesiano P, Amoroso A, Scolari F, Chen N, Zhang H, Lifton RP: Genome-wide association study identifies susceptibility loci for iga nephropathy. Nat Genet 2011;43:321-327.

12 Kiryluk K, Novak J, Gharavi AG: Pathogenesis of immunoglobulin a nephropathy: Recent insight from genetic studies. Ann Rev Med 2013;64:339-356.

-13 Li M, Foo JN, Wang JQ Low HQ, Tang XQ, Toh KY, Yin PR, Khor CC, Goh YF, Irwan ID, Xu RC, Andiappan AK, Bei JX, Rotzschke O, Chen MH, Cheng CY, Sun LD, Jiang GR, Wong TY, Lin HL, Aung T, Liao YH, Saw SM, Ye K, Ebstein RP, Chen QK, Shi W, Chew SH, Chen J, Zhang FR, Li SP, Xu G, Tai ES, Wang L, Chen N, Zhang XJ, Zeng YX, Zhang H, Liu ZH, Yu XQ Liu JJ: Identification of new susceptibility loci for iga nephropathy in han chinese. Nat Commun 2015;6:7270.

14 Kiryluk K, Li Y, Scolari F, Sanna-Cherchi S, Choi M, Verbitsky M, Fasel D, Lata S, Prakash S, Shapiro S, Fischman C, Snyder HJ, Appel G, Izzi C, Viola BF, Dallera N, Del Vecchio L, Barlassina C, Salvi E, Bertinetto FE, Amoroso A, Savoldi S, Rocchietti M, Amore A, Peruzzi L, Coppo R, Salvadori M, Ravani P, Magistroni R, Ghiggeri GM, Caridi G, Bodria M, Lugani F, Allegri L, Delsante M, Maiorana M, Magnano A, Frasca G, Boer E, Boscutti G, Ponticelli C, Mignani R, Marcantoni C, Di Landro D, Santoro D, Pani A, Polci R, Feriozzi S, Chicca S, Galliani M, Gigante M, Gesualdo L, Zamboli P, Battaglia GG, Garozzo M, Maixnerova D, Tesar V, Eitner F, Rauen T, Floege J, Kovacs T, Nagy J, Mucha K, Paczek L, Zaniew M, Mizerska-Wasiak M, Roszkowska-Blaim M, Pawlaczyk K, Gale D, Barratt J, Thibaudin L, Berthoux F, Canaud G, Boland A, Metzger M, Panzer U, Suzuki H, Goto S, Narita I, Caliskan Y, Xie J, Hou P, Chen N, Zhang H, Wyatt RJ, Novak J, Julian BA, Feehally J, Stengel B, Cusi D, Lifton RP, Gharavi AG: Discovery of new risk loci for iga nephropathy implicates genes involved in immunity against intestinal pathogens. Nat Genet 2014;46:1187-1196.

15 Gao J, Liu X, Wei L, Niu D, Wei J, Wang L, Ge H, Wang M, Yu Q, Jin T, Tian T, Dai Z, Fu R: Genetic variants of mcp-1 and ccr2 genes and iga nephropathy risk. Oncotarget 2016;7:77950-77957.

16 Gao J, Wei L, Wei J, Yao G, Wang L, Wang M, Liu X, Dai C, Jin T, Dai Z, Fu R: Tlr1 polymorphism rs4833095 as a risk factor for iga nephropathy in a chinese han population: A case-control study. Oncotarget 2016; 7:83031-83039.

17 Moore KW, de Waal Malefyt R, Coffman RL, O'Garra A: Interleukin-10 and the interleukin-10 receptor. Annu Rev Immunol 2001;19:683-765.

18 Liu Y, Wei SH, Ho AS, de Waal Malefyt R, Moore KW: Expression cloning and characterization of a human il-10 receptor. J Immunol (Baltimore) 1994;152:1821-1829.

19 Turner DM, Williams DM, Sankaran D, Lazarus M, Sinnott PJ, Hutchinson IV: An investigation of polymorphism in the interleukin-10 gene promoter. Eur J Immunogenet 1997;24:1-8.

20 Kube D, Platzer C, von Knethen A, Straub H, Bohlen H, Hafner M, Tesch H: Isolation of the human interleukin 10 promoter. Characterization of the promoter activity in burkitt's lymphoma cell lines. Cytokine 1995; 7:1-7.

-21 Iyer SS, Cheng G: Role of interleukin 10 transcriptional regulation in inflammation and autoimmune disease. Crit Rev Immunol 2012;32:23-63.

-22 Lazarus M, Hajeer AH, Turner D, Sinnott P, Worthington J, Ollier WE, Hutchinson IV: Genetic variation in the interleukin 10 gene promoter and systemic lupus erythematosus. J Rheumatol 1997;24:2314-2317.

-23 Abbott F, Ryan JJ, Ceska M, Matsushima K, Sarraf CE, Rees AJ: Interleukin-1 beta stimulates human mesangial cells to synthesize and release interleukins-6 and -8. Kidney Int 1991;40:597-605.

24 Takano M, Itoh N, Yayama K, Yamano M, Ohtani R, Okamoto H: Interleukin- 6 as a mediator responsible for inflammation-induced increase in plasma angiotensinogen. Biochem Pharmacol 1993;45:201-206.

-25 Kitching AR, Katerelos M, Mudge SJ, Tipping PG, Power DA, Holdsworth SR: Interleukin-10 inhibits experimental mesangial proliferative glomerulonephritis. Clin Exp Immunol 2002;128:36-43.

26 Stangou M, Bantis C, Skoularopoulou M, Korelidou L, Kouloukouriotou D, Scina M, Labropoulou IT, Kouri NM, Papagianni A, Efstratiadis G: Th1, th2 and treg/t17 cytokines in two types of proliferative glomerulonephritis. Indian J Nephrol 2016;26:159-166.

27 Hahn WH, Cho BS, Kim SD, Kim SK, Kang S: Interleukin-1 cluster gene polymorphisms in childhood iga nephropathy. Pediatr Nephrol 2009;24:1329-1336. 


\section{Kidney \\ Blood Pressure Research}

Kidney Blood Press Res 2017;42:89-98
\begin{tabular}{l|l}
\hline DOI: 10.1159/000471899 & $\begin{array}{l}\text { (c) } 2017 \text { The Author(s). Published by S. Karger AG, Basel } \\
\text { www.karger.com/kbr }\end{array}$ \\
Published online: March 31, 2017 &
\end{tabular}

Gao et al.: IL-10 Polymorphisms with Predisposition to IgA Nephropathy

28 Liu DJ, Liu Y, Ran LM, Li DT: Genetic variants in interleukin genes and susceptibility to iga nephropathy: A meta-analysis. DNA Cell Biol 2014;33:345-354.

-29 Cattran DC, Coppo R, Cook HT, Feehally J, Roberts IS, Troyanov S, Alpers CE, Amore A, Barratt J, Berthoux F, Bonsib S, Bruijn JA, D'Agati V, D'Amico G, Emancipator S, Emma F, Ferrario F, Fervenza FC, Florquin S, Fogo A, Geddes CC, Groene HJ, Haas M, Herzenberg AM, Hill PA, Hogg RJ, Hsu SI, Jennette JC, Joh K, Julian BA, Kawamura T, Lai FM, Leung CB, Li LS, Li PK, Liu ZH, Mackinnon B, Mezzano S, Schena FP, Tomino Y, Walker PD, Wang H, Weening JJ, Yoshikawa N, Zhang H: The oxford classification of iga nephropathy: Rationale, clinicopathological correlations, and classification. Kidney Int 2009;76:534-545.

30 Gabriel S, Ziaugra L, Tabbaa D: Snp genotyping using the sequenom massarray iplex platform. In: Current protocols in human genetics / editorial board, Jonathan L Haines, et al., Chapter 2:Unit 2.12-Unit 12.12., 2009.

31 Li S, Jin T, Zhang J, Lou H, Yang B, Li Y, Chen C, Zhang Y: Polymorphisms of treh, il4r and ccdc26 genes associated with risk of glioma. Cancer Epidemiol 2012;36:283-287.

-32 Thomas RK, Baker AC, DeBiasi RM, Winckler W, LaFramboise T, Lin WM, Wang M, Feng W, Zander T, MacConnaill LE, Lee JC, Nicoletti R, Hatton C, Goyette M, Girard L, Majmudar K, Ziaugra L, Wong K-K, Gabriel S, Beroukhim R, Peyton M, Barretina J, Dutt A, Emery C, Greulich H, Shah K, Sasaki H, Gazdar A, Minna J, Armstrong SA, Mellinghoff IK, Hodi FS, Dranoff G, Mischel PS, Cloughesy TF, Nelson SF, Liau LM, Mertz K, Rubin MA, Moch H, Loda M, Catalona W, Fletcher J, Signoretti S, Kaye F, Anderson KC, Demetri GD, Dummer R, Wagner S, Herlyn M, Sellers WR, Meyerson M, Garraway LA: High-throughput oncogene mutation profiling in human cancer. Nat Genet 2007;39:567-567.

33 Khoa PD, Sugiyama T, Yokochi T: Polymorphism of interleukin-10 promoter and tumor necrosis factor receptor ii in vietnamese patients with systemic lupus erythematosus. Clin Rheumatol 2005;24:11-13.

-34 Chin HJ, Na KY, Kim SJ, Oh KH, Kim YS, Lim CS, Kim S, Chae DW: Inteneukin-10 promoter polymorphism is associated with the predisposition to the development of iga nephropathy and focal segmental glomerulosclerosis in korea. J Korean Med Sci 2005;20:989-993.

-35 Bantis C, Heering PJ, Aker S, Klein-Vehne N, Grabensee B, Ivens K: Association of interleukin-10 gene g-1082a polymorphism with the progression of primary glomerulonephritis. Kidney Int 2004;66:288-294.

36 Wang M, Xu F, Zhang J, Chen B, Dong S: Association Between IL-10 Gene Promote Polymorphisms and IgA Nephropathy. Chinese J Integrated Traditional and Western Nephrol 2008:782-784.

37 Reynard MP, Turner D, Navarrete CV: Allele frequencies of polymorphisms of the tumour necrosis factoralpha, interleukin-10, interferon-gamma and interleukin-2 genes in a North European Caucasoid group from the UK. Eur J Immunogenet 2000;27:241-249.

-38 Rees LE, Wood NA, Gillespie KM, Lai KN, Gaston K, Mathieson PW: The interleukin-10-1082 g/a polymorphism: Allele frequency in different populations and functional significance. Cell Mol Life Sci 2002;59:560-569.

-39 Steinke JW, Barekzi E, Hagman J, Borish L: Functional analysis of -571 Il-10 promoter polymorphism reveals a repressor element controlled by sp1. J Immunol (Baltimore) 2004;173:3215-3222.

-40 Perrey C, Pravica V, Sinnott PJ, Hutchinson IV: Genotyping for polymorphisms in interferon-gamma, interleukin-10, transforming growth factor-beta 1 and tumour necrosis factor-alpha genes: A technical report. Transplant Immunol 1998;6:193-197. 